\title{
The Effects of Mobile Payment Dimensions toward Continuance Intention in Surabaya
}

\author{
Sandra Yunita and Erna Andajani \\ University of Surabaya, Surabaya \\ e-mail: 5120067.sandra@gmail.com
}

\begin{abstract}
The 4.0 industrial revolution allows people to make payments using mobile devices which is called mobile payment. Mobile payment users in Indonesia have enlarged a significant improvement in the last few years. However, the use of mobile payment in Indonesia has not dominated yet. Most of the payments that they use are ATM Transfers, debit cards, and internet banking. These indicate the lack of continuance intention in using a mobile payment. The aim of this study is to examine the effects of mobile payments dimension (mobility, customization, security, reputation), service quality toward continuance intention through trust, and also the effects of trust toward continuance intention through perceived risk. The data used in this study are obtained through a research questionnaire. Respondents in this study were 170 Go-Pay and OVO users domiciled in Surabaya who made transactions with Go-Pay and OVO at least twice in the last few months. The sampling method of this study was non-probability sampling. This study uses a quantitative approach with the Structural Equation Modeling (SEM) method for statistical test. SEM analysis was carried out using the Analysis of Moment Structures (AMOS). The results of this study indicate that mobility and security have a significant positive effect on trust. On the other hand customization, reputation, and service quality do not affect trust. Trust has a significant positive effect on continuance intention and perceived risk. Meanwhile, the perceived risk made a significant negative effect on continuance intention.
\end{abstract}

Keywords-Continuance Intention, Mobility, Perceived Risk, Security, Trust.

\section{INTRODUCTION}

A DVANCED technology has entered Indonesia along with the development of the industrial era 4.0. This development is a result of the globalization process. One of the technologies developed in the industrial era 4.0 is digital economy [30]. Digital economy covers various digital businesses that are developing in Indonesia, such as ondemand transportation services (Go-Jek and Grab), ecommerce businesses (Tokopedia, Lazada, Bukalapak, etc.), and financial technology services or better known as FinTech [38]. FinTech has had an impact on Indonesian society in the form of changes to the payment system with better services, more choices, and lower prices [6]. FinTech is the result of the development of cellular technology and near-field communications (NFC). ITU states that the existence of FinTech changes the way humans pay for goods or services, even sending money abroad [18]. The conventional wallet has now been replaced with a smartphone. The main driver for the development of mobile payments is the development of mobile devices. Mobile payment is a financial transaction and service that can be done using a mobile device such as a cellphone or tablet [18]. These financial services can be connected or not directly connected to a bank account. Mobile payment is different from mobile money transfer and mobile banking [18]. Mobile money transfer is done by an individual to another individual. Transfers can be done anywhere. Mobile banking provides services for users to manage their bank accounts with a mobile device. While mobile payments talk about transactions with merchants and the user.

In Indonesia, mobile payment services have been developing since 2007. Telkomsel started the mobile payment service with T-Cash. The service is USSD based which uses short messages (SMS) for the transaction. Along with the development of technology, currently mobile payment in Indonesia has 2 models, chip based and server based [1]. Chip based mobile payment models are in the forms of cards that store electronic money, such as Mandiri e-money, BCA Flazz cards, etc. While the server based model is in the form of applications, such as Go-Pay, OVO, Sakuku, etc. The server based model is also known as a mobile wallets. Based on the FT Confidential Research Mobile Payment survey [21] mobile payments and prepaid cash cards make up the top five non-cash payments that are popular in Indonesia. Both of these methods of payment are newly developed in Indonesia compared to other methods of payment. The results of the FT Confidential Research Mobile Payment survey [21] and Bank Indonesia calculations [7] regarding the amount of electronic money in circulation, shows that more and more Indonesians are using electronic money as a payment, one of which is mobile payment. Mobile payment users in Indonesia are rapidly improved. This is showed by the results of the PricewaterhouseCoopers survey conducted in Southeast Asian and Middle Eastern countries. Indonesia was ranked 5 th in the country that experienced an increase in mobile payment users [34].

In 2018, mobile payment users in Indonesia have reached $38 \%$, while in 2019 it has reached $47 \%$. This figure shows that more people in Indonesia are using mobile payment. The increase that occurred from 2018 to 2019 was quite significant. Nevertheless, most Indonesians still use other forms of payment. Morgan Stanley's research results [29] showed the use of cash as a payment method with a percentage of $38 \%$. This figure is the highest percentage compared to payments using mobile payment $(20 \%)$ in daily transactions. The results of the FT Confidential Research Mobile Payment study show that ATM transfers are the most 
The $1^{\text {st }}$ International Conference on Business and Engineering Management (IConBEM)

February $1^{\text {st }} 2020$, Institut Teknologi Sepuluh Nopember, Surabaya, Indonesia

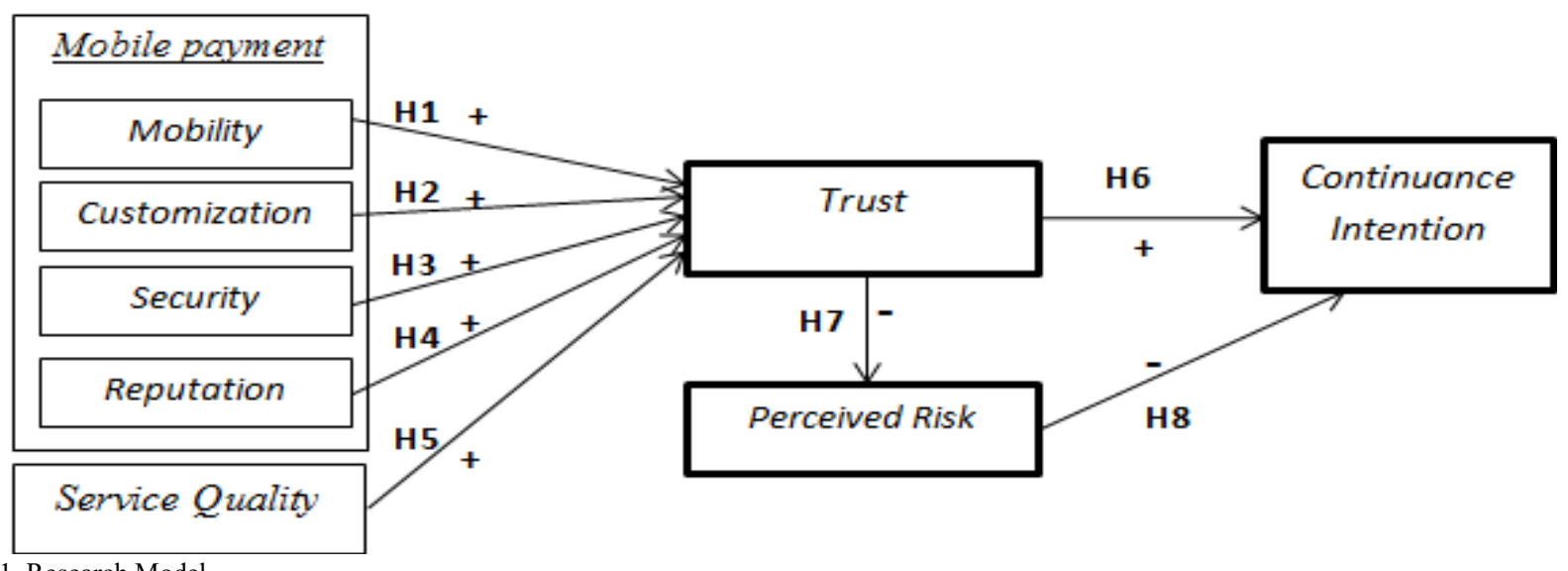

Figure 1. Research Model

popular payment method in Indonesia, followed by debit cards and internet banking, even it has been seen a very significant difference between the popularity of ATM transfers and mobile payment in Indonesia. The gap shows the lack of continuance intention of mobile payment as the main payment instrument in conducting transactions.

Based on a descriptive analysis of Go-Pay users, a mobile payment service provider, in Surabaya conducted by Huwaydi, et al. of 646 respondents, there were 339 respondents who used Go-Pay once a month [17]. 178 respondents used Go-Pay three times a month when making payments. The research respondents were dominated by students with the range of age 7-21 years. This study supports the problem of the lack of continuance intention mobile payment in payment transactions.

The reasons for using mobile payment are easier to use, simpler, more efficient, safer, better promos and incentives, and better management [35]. Go-Pay CEO, Aldi Haryopratomo, revealed that trust is the key to a mobile payment that can be adopted by the public. Public trust is built on mobile payments in everyday transactions [35]. However there are those who argue that payments using mobile payment have a system that is quite complicated because they have to open the application or scan the QR code [8]. Transactions made with mobile payments are financial transactions through wireless networks [28]. Mobile networks are not always stable and can cause security problems when network outages occur. These security problems include money security and the risk of privacy disturbances [39]. Trust (trust) becomes very important in this case. Trust is a determinant in predicting the behavior of using mobile payments. Trust is very important to overcome uncertain situations, encourage future transactions, and develop long-term relationships [40]. Building trust in mobile payment users is very important to support the tendency to use mobile payments in a sustainable manner.

Research conducted by Shao et al. [36] found that one's tendency to use mobile payments on an ongoing basis (continuance intention) was positively influenced by trust in mobile payment service providers. Trust plays an important role in improving the transaction behavior of mobile payment users [36]. Trust is influenced by mobility, customization, security, and reputation of the mobile payment service. This study wants to explain the influence of available mobile payment services on continuance intention in AliPay and WechatPay users in China. This influence is mediated by trusts. Mobile payment services in this study are seen from the dimensions of mobility, customization, security, and reputation. Shao et al. [36] shows that trust negatively influences perceived risk and perceived risk negatively influences continuance intention. So the influence of trust on continuance intention is mediated negatively by perceived risk. Lu et al. [26] also found a process of trust transfer with perceived risk as a mediation of one's tendency to use mobile payment.

Another study about continuance intention on mobile payments was conducted by Dlodlo [9]. This study examines the relationship between service quality, trust, user satisfaction, and post-adoption intention on mobile payment services. In this study, continuance intention is influenced by service quality of mobile payment service providers. The service quality dimensions are reliability, responsiveness, assurance, and personalization. Mediation variables in this study are trust and satisfaction. This research was conducted in South Africa. The results of this study found that service quality affects continuance intention with trust mediation. However, service quality does not affect satisfaction. Trust influences satisfaction and satisfaction affects continuance intention. Zhou [41] found that service quality was a factor influencing trust. Service quality has a large influence on trust. Service quality can be a strong signal of trust. Mobile payment service user trust will be reduced if the service provider cannot provide reliability, speed, and personalization. These three things have an impact on the ability and integrity of service providers to provide quality service which results in a decrease in trust. So it is important for service providers to provide good service quality so that the trust of service users increases. Increased trust can increase continuance intention to use mobile payments

This study adapted the research model conducted by Shao et al. [36] with mobile payment as the independent variable and continuance intention as the dependent variable. Mobile payment researched by Shao et al. [36] has dimensions of mobility, customization, security, and reputation. The effect of mobile payment on continuance intention is mediated by trust and perceived risk. The research model was modified by adding service quality which is an independent variable in the Dlodlo study [9]. 
The $1^{\text {st }}$ International Conference on Business and Engineering Management (IConBEM)

February $1^{\text {st }} 2020$, Institut Teknologi Sepuluh Nopember, Surabaya, Indonesia

Table 1.

Descriptive Research Demography

\begin{tabular}{|c|c|}
\hline Profile & Amounts (\%) \\
\hline \multicolumn{2}{|l|}{ Age } \\
\hline 18-22 Years old & $46(27,1 \%)$ \\
\hline 23-30 Years old & $98(57,6 \%)$ \\
\hline $31-40$ Years old & $20(11,8 \%)$ \\
\hline$>40$ Years old & $6(3,5 \%)$ \\
\hline
\end{tabular}

\begin{tabular}{lr}
\hline Gender & \\
Male & $61(35,9 \%)$ \\
Female & $109(64,1 \%)$
\end{tabular}

\begin{tabular}{ll}
\hline Occupation & \\
Student & $59(34,7 \%)$ \\
Employee & $83(48,8 \%)$ \\
Etc & $28(16,5 \%)$ \\
\end{tabular}

\begin{tabular}{ll}
\hline Salary per month & \\
$\quad<$ IDR 3.000 .000 & $48(28,2 \%)$ \\
IDR $3.000 .000-$ IDR 5.000 .000 & $75(44,1 \%)$ \\
$>$ IDR 5.000 .000 & $47(27,6 \%)$
\end{tabular}

\begin{tabular}{lr}
\hline Last Education & \\
High School & $31(18,2 \%)$ \\
Associate Degree & $3(1,8 \%)$ \\
Bachelor Degree & $120(70,6 \%)$ \\
Master Degree & $16(9,4 \%)$
\end{tabular}

Frequency of usage of Go-Pay and OVO services (last 1 month)
2-5 times
$44(25,9 \%)$
6-10 times
$71(41,8 \%)$
$>10$ times

$55(32,4 \%)$

Mobile payment is a method of payment using mobile devices. The results of a survey of the Indonesian Internet Service Providers Association [2], as many as $70.96 \%$ of urban communities in Indonesia already have smartphones / tablets. Smartphones are used to access the internet by most (59.31\%) urban communities. Of the total survey respondents, $58.08 \%$ came from Java with $57.70 \%$ internet users. There are several big cities in Java, one of which is Surabaya. The city of Surabaya is one of the largest cities in Java based on its population [10]. In addition, the results of a recent survey by a leading research company in Indonesia showed eight major cities have used mobile payments with the e-wallet model [20]. Surabaya is one of the eight big cities. Thus, this study chose the city of Surabaya as a research subject.

Mobile payment in Indonesia is currently dominated by ewallet models, such as Go-Pay, OVO, and T-Cash / LinkAja [35]. Mobile payment with e-wallet model provides financial transaction services in close range. Mobile payment model ewallet users can make payment transactions in the area of the seller. Based on the FT Confidential Research Mobile Payment survey [21], Go-Pay is the most popular mobile payment service provider in Indonesia. Go-Pay is used by almost $75 \%$ of mobile payment users who are respondents to
Table 2.

Result of Measurement Model

\begin{tabular}{lllll}
\hline \hline No & Test & Criteria & Result & Notes \\
\hline 1 & CMIN/DF & $\leq 2$ & 1,297 & Good fit \\
2 & RMSEA & $\leq 0,08$ & 0,042 & Good fit \\
3 & GFI & $\geq 0,90$ & 0,866 & Marginal fit \\
4 & CFI & $\geq 0,90$ & 0,955 & Good fit \\
5 & TLI & $\geq 0,90$ & 0,946 & Good fit \\
\hline \hline
\end{tabular}

the survey. However, Go-Pay is competing with newcomers, namely OVO. OVO is used by $42 \%$ of mobile payment users. The survey results are supported by the 2018 FinTech report from DailySocial with the Financial Services Authority [35]. Seeing the popularity and competition of the two mobile payment service providers in Indonesia, Go-Pay and OVO were determined to be the object of this study. This is supported by research Shao et al. [36] which uses two of the most popular mobile payments in China, namely Alipay and WechatPay, as research objects.

\section{A. Effect of Mobility on Trust}

Mobile payment has four dimensions, namely mobility, customization, security, and reputation [36]. The mobility dimension according to Shao et al. [36] is a relative advantage to mobile payments that can be accessed anytime and anywhere. Mobility gives consumers the freedom to be able to trade at any time and place. [22] Mobility is the most prominent dimension in mobile payment. Mobility allows consumers to make transactions only by carrying a mobile device [3]. Consumers will trust and often use a mobile service if they accept mobile services as a unique tool and are ready to provide a variety of things that support payment services [5]. Mobility is an advantage of mobile payments that are not owned by other types of payment services. With the concept of freedom of transaction, mobility is unique and supports unlimited transactions of time and place, so that mobility can increase consumer trust in using mobile payments. This is supported by research Shao et al. [36] which proves that mobility has a positive effect on trust.

H1: mobility has a positive effect on trust

\section{B. Effect of Customization on Trust}

The relative advantage of mobile payment is customization. Customization is indicated by the application home page settings that can be set according to the billing / purchase object that is often used by consumers. In OVO applications, they have option for PLN, phone credit, Data Packages, BPJS, etc. In addition, users can also choose to pay using cash, points, or combining them when making transactions using OVO. Customization provides the ability for consumers to manage mobile payment applications in accordance with their wishes. This ability can increase the trust of mobile payment users because they can transact according to the arrangements they make [36]. Mobile payment users are becoming increasingly comfortable in conducting transactions. Customization is one of the most important trust formers in the e-commerce market [16]. It has the ability to interpret trust properly [23]. It is also unique to mobile payments that other payment instruments do not have. 
The $1^{\text {st }}$ International Conference on Business and Engineering Management (IConBEM)

February $1^{\text {st }} 2020$, Institut Teknologi Sepuluh Nopember, Surabaya, Indonesia

Table 3.

Result of Validity and Reliability Test

\begin{tabular}{|c|c|c|c|c|}
\hline Factor & Item & Standard Loading & AVE & CR \\
\hline \multirow[t]{3}{*}{ Mobility } & M1 & 0,808 & \multirow{3}{*}{0,560} & \multirow{3}{*}{0,790} \\
\hline & M2 & 0,616 & & \\
\hline & M3 & 0,805 & & \\
\hline \multirow[t]{3}{*}{ Customization } & $\mathrm{C} 1$ & 0,662 & \multirow{3}{*}{0,525} & \multirow{3}{*}{0,767} \\
\hline & $\mathrm{C} 2$ & 0,677 & & \\
\hline & $\mathrm{C} 3$ & 0,824 & & \\
\hline \multirow[t]{3}{*}{ Security } & S1 & 0,818 & \multirow{3}{*}{0,711} & \multirow{3}{*}{0,881} \\
\hline & S2 & 0,877 & & \\
\hline & S3 & 0,834 & & \\
\hline \multirow[t]{3}{*}{ Reputation } & $\mathrm{R} 1$ & 0,655 & \multirow{3}{*}{0,508} & \multirow{3}{*}{0,752} \\
\hline & $\mathrm{R} 2$ & 0,850 & & \\
\hline & $\mathrm{R} 3$ & 0,610 & & \\
\hline \multirow[t]{4}{*}{ Service Quality } & SQ1 & 0,755 & \multirow{4}{*}{0,525} & \multirow{4}{*}{0,812} \\
\hline & SQ2 & 0,782 & & \\
\hline & SQ3 & 0,807 & & \\
\hline & SQ4 & 0,517 & & \\
\hline \multirow[t]{4}{*}{ Trust } & $\mathrm{T} 1$ & 0,822 & \multirow{4}{*}{0,554} & \multirow{4}{*}{0,831} \\
\hline & $\mathrm{T} 2$ & 0,799 & & \\
\hline & $\mathrm{T} 3$ & 0,684 & & \\
\hline & $\mathrm{T} 4$ & 0,659 & & \\
\hline \multirow[t]{3}{*}{ Perceived Risk } & PR1 & 0,633 & \multirow{3}{*}{0,506} & \multirow{3}{*}{0,750} \\
\hline & PR2 & 0,845 & & \\
\hline & PR3 & 0,634 & & \\
\hline \multirow{3}{*}{$\begin{array}{l}\text { Continuance } \\
\text { Intention }\end{array}$} & CI1 & 0,715 & \multirow{3}{*}{0,585} & \multirow{3}{*}{0,807} \\
\hline & CI2 & 0,691 & & \\
\hline & CI3 & 0,875 & & \\
\hline
\end{tabular}

It provides freedom of regulation that can increase trust in mobile payment users because users can make transactions conveniently as they wish. Shao et al. [36] found a positive effect of customization on trust in the use of mobile payments.

H2: customization has a positive effect on trust.

\section{Effect of Security on Trust}

Security is important in making consumers feel safe when making transactions that may be at risk. Security symbolizes the perception of mobile payment users of the security and reliability provided by mobile payment service providers, such as guarantees, rules, and promises of transactions in mobile payments [36]. The existence of protection for consumers through security can increase trust [36]. According to Kim et al. [22], consumers' perceptions about security guarantees are very important in building trusts in electronic payment systems. Mobile payment service is an online-based service with a minimum of face-to-face contact between users and service providers. Trust in the context of mobile payment is closely related to security, it can be interpreted as trust in security and freedom from threats when transactions are made [33]. When mobile payment users use mobile payment services with guaranteed secure transactions, users will increasingly trust the mobile payment [11].
Table 4.

Result of Structural Model Test

\begin{tabular}{ccccc}
\hline \hline No & Test & Criteria & Result & Notes \\
\hline 1 & CMIN/DF & $\leq 2$ & 1,274 & Good fit \\
2 & RMSEA & $\leq 0,08$ & 0,040 & Good fit \\
3 & GFI & $\geq 0,90$ & 0,865 & Marginal fit \\
4 & CFI & $\geq 0,90$ & 0,957 & Good fit \\
5 & TLI & $\geq 0,90$ & 0,950 & Good fit \\
\hline \hline
\end{tabular}

Research Shao et al. [36] states that security has a positive effect on trust.

H3: security has a positive effect on trust.

\section{Effect on Reputation on Trust}

Service provider reputation is very important to attract consumers. Service providers with a bad reputation will lose consumers [4]. In addition to attracting consumers, the reputation of service providers has an important role in encouraging consumer trust [36]. Yu et al. [40] states that service providers must consider building reputation very well to increase trust in their users. A good reputation not only benefits existing products, but also benefits new products. When service providers with a good reputation develop cellular products, they tend to attract and retain users. New cellular object user trust can not only be transferred from the previous trust but also results from a good service provider reputation [40]. This is supported by the results of research Shao et al. [36] who found that reputation had a positive influence on trust.

H4: reputation has a positive effect on trust.

\section{E. Effect of Service Quality on Trust}

Service quality is the main factor to form the trust [41] Good quality of services provided is a sign that service providers have the ability and benevolence. Trust cannot be formed in mobile payment users if the service provider does not provide good service to the user. Quality services convey to users the ability of service providers to meet the demands of service provision, which can increase trust in users [24]. Service quality in mobile payments is shaped by the speed of response, reliability, guarantees, and personalization. Rapid response can increase user perceptions of the ability of service providers to meet user needs. Conversely, a slow response can make users doubt the ability of service providers. Reliability is related to the timeliness of service delivery when needed. High reliability can increase user confidence in the ability and benevolence of service providers. User confidence will decrease when the services provided are not professional. A personal approach is needed in the process of delivering service quality to increase user confidence. Greeting the username on the mobile payment application interface page will make the user feel the mobile payment service is personally provided for him. Service quality aspects influence the ability and benevolence dimensions of trust. So the better the service quality, the higher the trust that is formed on mobile payment users. Zhou 
The $1^{\text {st }}$ International Conference on Business and Engineering Management (IConBEM)

February $1^{\text {st }} 2020$, Institut Teknologi Sepuluh Nopember, Surabaya, Indonesia

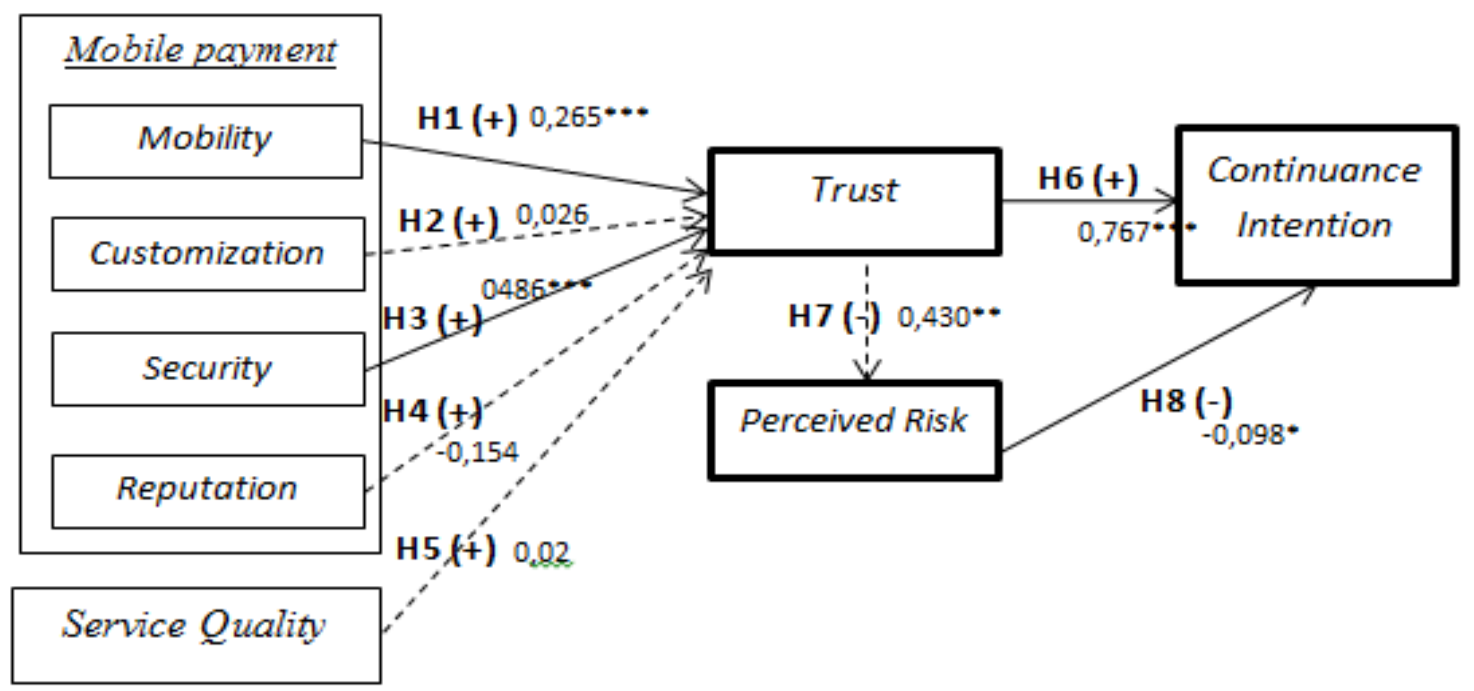

Figure 2. Result of Structural Model (Notes : *** p-value $\leq 0,001,{ }^{* *}$-value $\leq 0,05,{ }^{*}$-value $\leq 0,1$ )

[41] states that service quality has a positive effect on trust. This statement is supported by Dlodlo's research [9].

H5: service quality has a positive effect on trust.

\section{F. Effect of Trust on Continuance Intention}

Consumers who have the perception that mobile payment service providers are reliable in making transactions will tend to use it continuously [27]. Low trust can cause users to doubt and do not want to do online transactions [33]. The process that occurs in transactions via mobile payment cannot be seen by the user. Trust in payment systems like this will help reduce the need to understand, control, and supervise activities, so that transactions become easier and more efficient to use [11]. Trust has become an important factor in increasing the use of e-commerce. This was stated by Luo et al in Dlodlo [9]. Therefore, Dlodlo argues that trust is an important variable in shaping the sustainable use of mobile payments [9]. Trust has a positive effect on continuance intention on mobile payment [36]. This is supported by the results of Dlodlo's research [9].

H6: trust has a positive effect on continuance intention.

\section{G. Effect of Trust on Perceived Risk}

The concept of trust in online services is based on the relationship between users and service providers that are built through mobile networks. The relationship is very risky because there is no face-to-face between users and service providers. In addition, risks on mobile networks are attacks from hackers, interception of information so that information cannot be conveyed, as well as infection from viruses [9]. This can result in lost money due to being undelivered by the system. In addition, users' personal data can also be hacked and used for other things without the user's knowledge. The possibility of these risks making service providers must build trust that they can prevent the occurrence of risks. The higher the trust, the lower the perceived risk for mobile payment users. Users who have deep trust in the service provider will increasingly ignore the risks that might occur. Several studies have revealed that perceived risk influences trust. One such study is the Shuhaiber research [37] which states that perceived risk negatively affects trust. In contrast, the study of Lu et al. [26] found that trust negatively affects perceived risk. Research by Shao et al. [36] find something similar. H7: trust has a negative effect on perceived risk.

\section{H. Effect of Perceived Risk on Continuance Intention}

Perceived risk is the perception of the occurrence of risk to mobile payment users. Several studies disclosed by LiébanaCabanillas [24] explain that perceived risk is the user's perception of uncertainty and consequences due to conducting transactions with mobile payment. This perception can reduce the desire to use continuously (continuance intention). The higher the perceived risk, the lower the continuance intention in using mobile payment. Research by $\mathrm{Lu}$ et al. [26] found that perceived risk has a negative effect on continuance intention on mobile payment. Liébana-Cabanillas research [24] also found a negative effect of perceived risk on continuance intention in mobile payments with the type of Near Field Communication (NFC). These studies are supported by the results of research Shao et al. [36] which states that perceived risk has a negative influence on the continuous intention to use mobile payments. H8: perceived risk has a negative effect on continuance intention.

\section{METHOD}

The target population of this study is the people of Surabaya. Criteria for research participants are people domiciled in Surabaya who have conducted transactions using the mobile payment service Go-Pay and OVO. The transaction has been conducted at least twice in the past month. Research participants have a minimum high school education level with the assumption that participants can understand each sentence of the research questionnaire. The age of respondents in this study was 18 years and over. The sampling technique that will be used in this study is nonprobability sampling with a purposive sampling design. Nonprobability sampling was chosen because not everyone in the population had the opportunity to be selected as a research sample [32]. Purposive sampling design is a sampling design chosen based on the research criteria [32]. 
The $1^{\text {st }}$ International Conference on Business and Engineering Management (IConBEM)

February $1^{\text {st }} 2020$, Institut Teknologi Sepuluh Nopember, Surabaya, Indonesia

This research will use Structural Equation Model (SEM) analysis technique. The analysis technique requires 100-400 samples [14]. Based on the Maximum Likelihood Estimation (MLE) model, the samples needed for SEM analysis techniques are 100-200 samples [12]. In this study, a sample of 170 respondents is needed. Processing statistical data using Analysis of Moment Structures (AMOS). The stages of data processing and hypothesis testing in this study are as follows.

\section{A. Validity testing}

Validity is the ability of a measurement or several measurements to measure the concept being studied accurately [15]. The more validity testing methods carried out on a measuring instrument, the more valid the measuring instrument. This study uses the construct validity test, confirmatory factor analysis (CFA), and average variance extracted (AVE). The construct validity test is examined using SPSS for windows. The construct validity test is a test of questionnaire items by looking at the Pearson correlation coefficient of each item with the total score obtained. If the correlation coefficient between each statement and the total score produces a significance value of less than $0.05(\alpha=5 \%)$, then the statement is declared valid. If the construct validity test on 30 respondents shows good validity, the measurement can be used to collect data in accordance with the required amount. CFA validity test is done using factor analysis. CFA tests the validity of statement items in the research measuring instrument by looking at standardize loading. A measuring instrument statement can be said to be valid if it has a standardize loading value above 0.5 . AVE test is performed to see the suitability of indicators with latent constructs. The high AVE value indicates that the indicator has represented a well-developed latent construct. AVE values received is $\geq 0.50$ [15].

\section{B. Reliability testing}

Reliability testing is to examine the level of consistency of measurements between indicators (multiple measurement) of a variable [15]. The reliability testing of this study was carried out by cronbach's alpha reliability test and calculating composite reliability (CR). Cronbach's alpha reliability test was performed on 30 initial data. The software used to do this test is SPSS for windows. If the Cronbach's alpha value is more than 0.6, the measuring instrument can be declared reliable. While the CR test is done by looking at the value of CR. CR values received is $\mathrm{CR} \geq 0.70$ [14].

\section{Structural Equation Model (SEM)}

SEM is used to process the data obtained in this study. The sample size used in this study was adjusted to the SEM method, which is 170 samples. Maximum Likelihood is used as an estimation technique in this study. Maximum Likelihood is the default of AMOS and the most popular technique used in research that uses SEM. In this research, the model fitness test is examined by the Goodness of Fit (GOF) index.

\section{Hypothesis Testing}

Testing the hypothesis in this study using a structural model in SEM. Hypothesis testing in this study is examined by looking at the critical ratio and the level of significance. The level of significance $(\alpha)$ used in this study was $0.1 \%, 5 \%$, and $10 \%$. The value of the critical ratio (t-value) so that the hypothesis can be accepted is $\geq 3.291$ for a significance level of $0.1 \% ; \geq 1.96$ for the $5 \%$ significance level; and $\geq 1,645$ for the significance level of 10 [31].

\section{RESULTS AND DISCUSSION}

From the questionnaire distributed to the Go-Pay and OVO users in the city of Surabaya, a total of 170 respondents were obtained. Descriptive demographic data of respondents in this study can be seen in Table 1 .

Respondent demographic data obtained in this study are age range, gender, occupation, average income per month, last education, and frequency of use of Go-Pay and OVO services in 1 last month. Respondents in this study were dominated by the range of age 23-30 years, female gender, employee work, average income of IDR 3,000,000 - IDR $5,000,000$ per month, with the last education of bachelor.

In addition, respondents with more than 10 times the frequency of using Go-Pay and OVO services in the past 1 month also dominated this study. While the fewest were respondents aged over 40 years and respondents with the last education level of D3. A total of 30 initial respondent data have been tested for construct validity and Cronbach's alpha reliability to ensure the questionnaire used is valid and reliable. The construct validity test results showed all items had a Pearson correlation value of more than 0.3 . While the Cronbach's Alpha value is more than 0.6. So it can be concluded that the initial data is valid and reliable.

After obtaining 170 respondents' data, a confirmatory factor analysis (CFA) test was performed. First, the goodness of fit of the measurement model is tested. The goodness of fit test results of the measurement model can be seen in Table 2 .

Next is validity and reliability testing. The AVE and CR values are calculated from the data obtained. With AVE value and standardized loading each construct more than 0.5 , it can be concluded that the convergent validity has been fulfilled. All indicators of each research variable have shown good convergent validity on each indicator and research construct. In addition, each variable has a $\mathrm{CR}$ value $>0.70$. So it can be concluded that all research constructs used in this study are valid and reliable. The results of the validity and reliability tests can be seen in Table 3 .

After testing the validity and reliability, the structural model testing continues. Structural model analysis is carried out to test the influence between variables. In other words, structural model analysis is carried out for hypothesis testing. If the indicator of a construct has a significant estimate value on the construct to be measured, the indicator can be used in structural analysis models. Significance can be seen from the size of the critical ratio or p-value of the estimate value. A relationship is called statistically significant if the critical ratio value $>1.96$ or $p$-value $\leq 0.05(5 \%)$.

If the influence of a construct on another construct has a significance level of $0.1 \%$ and produces a Critical Ratio value $>3.291$, the research hypothesis is stated supported by the results of this study. If the effect of a construct on another 
The $1^{\text {st }}$ International Conference on Business and Engineering Management (IConBEM)

February $1^{\text {st }} 2020$, Institut Teknologi Sepuluh Nopember, Surabaya, Indonesia

construct produces a Critical Ratio $>1.96$ with a significance level of $5 \%$, the research hypothesis is declared supported by the results of this study. If the significance level is $10 \%$ and the resulting critical ratio value $>1,645$, the research hypothesis is stated and supported by the results of this study. Hypotheses that have proven to be significant must consider the direction and strength of their relationship by looking at the estimated values in the output standardized regression weights. The magnitude of influence between variables is done by looking at the estimated value on each path. The influence of one variable with other variables will be even greater if the estimated value generated is greater. Figure 2 shows the results of testing eight research hypotheses.

Hypothesis 1 shows a significant positive effect between Mobility and Trust on GoPay and OVO with a Critical Ratio of 3.964 and a P-value $<0.001$ or $0.1 \%$. Critical Ratio Value of Hypothesis 1> 3,291. So it can be concluded that hypothesis 1 is supported by the results of this study. that mobility has a significant positive effect on trust. The results of this study support the results of research conducted by Shao et al. [36] which states that mobility has a positive effect on trust. The research explains that mobility is unique with the concept of freedom of transaction that can increase trust in mobile payment users. Consumer confidence will increase if they receive a mobile payment service that provides a unique service with a variety of things to support payment services [5]. Mobility supports payment services by giving users freedom of transactions that is not limited in time and place. Mobility is a uniqueness that is only owned by mobile payment and is not owned by other payment instruments.

While the results of the hypothesis 2 test have a Critical Ratio of 0.247 and a P-value of 0.805 . These results indicate there is no influence between Customization and Trust on GoPay and OVO. So hypothesis 2 is not supported by the results of this study. The fact is that mobile payment is a means of payment in the developing cashless era. From the interview results, several respondents stated whether or not customization had an effect as long as it could still be used to pay. Because paying is the main function of the mobile payment application.

Settings on the application are only added value, but do not affect trust in the user. In addition, customization related to payments on GoPay and OVO currently depends on the facilities provided by the relevant merchants. Some merchants only provide mobile payment facilities with a QR code scan, others provide mobile payment facilities by entering the registered telephone number of the user. For OVO users, there are merchants that provide payment facilities using OVO cash and OVO points. But there are also merchants who only provide payment facilities using OVO cash and do not provide payment facilities using OVO points, such as Tokopedia. This causes GoPay and OVO users not to fully get freedom of regulation regarding payment processing. So that customization does not affect the trust of GoPay and OVO users. The average respondent interviewed stated that mobile payment has become a necessity at this time. Respondents felt there were payment needs that were met by mobile payment. Meeting these needs increases respondents' trust in mobile payments.
Hypothesis 3 test results showed a positive and significant effect between Security and Trust with a Critical Ratio value of 6.119 and a P-value $<0.001$ or $0.1 \%$. So it can be concluded that hypothesis 3 is supported by the results of this study. These results support the results of research Shao et al. [36] which states that security has a positive effect on trust. In the research of Shao et al. [36] explained that security symbolizes the perception of mobile payment users of the security provided by mobile payment service providers. Xin et al. in Shao et al. [36] stated that trust in mobile payment users can increase if there is protection for consumers through security. Kim et al. [22] states that consumers' perceptions of security guarantees are very important in building trusts in electronic payment systems. Mobile payment users will increasingly trust mobile payments when users use mobile payment services with guaranteed secure transactions [11]. Thus, the results of this study are in line with previous studies.

Security is the most influential dimension on trust seen from the estimated value. Security has the largest estimated value in the results of this study. This shows that security is the most important thing in increasing the trust of mobile payment users. According to several respondents interviewed, security is the most important and influential on the trust of respondents in Go-Pay and OVO. Personal data and funds deposited are important for respondents. Personal data concerns user privacy, while deposit funds are the user's property. The more guaranteed the security of personal data and funds deposited on Go-Pay and OVO, the higher the respondent's trust in Go-Pay and OVO. In the event of personal data leakage or loss of funds, respondents' trust in Go-Pay and OVO will be reduced.

While hypothesis 4 shows there is no influence between Reputation and Trust with a Critical Ratio of -1.284 and Pvalue of 0.199 . Thus hypothesis 4 is not supported by the results of this study. Reputation on mobile payment has no relationship with Trust. Hypothesis 5 shows there is no influence of Service Quality and Trust with a Critical Ratio value of 0.180 and P-value of 0.857 . This means that hypothesis 5 is not supported by the results of this study. Thus, service quality has no relationship with trust. From the interviews, several respondents of this study stated that the use of Go-Pay and OVO has now become a habit and daily needs as a means of payment. In using Go-Pay and OVO, respondents do not see reputation and service quality, but instead focus on payment needs. Fulfillment of daily payment needs that affect trust in Go-Pay and OVO users. In addition, respondents are also accustomed to using Go-Pay and OVO in daily transactions. So that reputation and service quality do not affect their trust in Go-Pay and OVO.

Furthermore, hypothesis 6 has a Critical Ratio value of 6.752 and a P-value $<0.001$ or $0.1 \%$. The Critical Ratio value is greater than 3,291. Hypothesis 6 results show that there is a positive and significant effect between Trust and Continuance Intention. So hypothesis 6 is supported by the results of this study. The results of this study support the results of previous studies conducted by Shao et al. [36]. This study is also in line with Dlodlo's research [9] which states that trust is an important variable in shaping the sustainable use of mobile payments. According to McKnight et al. [27] 
The $1^{\text {st }}$ International Conference on Business and Engineering Management (IConBEM)

February $1^{\text {st }} 2020$, Institut Teknologi Sepuluh Nopember, Surabaya, Indonesia

Asim, consumers, who have a perception that a trusted mobile payment service provider in conducting transactions will tend to use the service on an ongoing basis. Septiani et al. [33] stated that low trust can lead to feelings of doubt on the user and does not want to continue using the service in the transaction. Dlodlo states that trust has an important role in creating satisfied users and the expected results as the end of the transaction process [9]. The estimated value that is owned is the highest value compared to other constructs. So it can be concluded that trust has a very large influence on continuance intention. Thus, trust is the most important factor in shaping the sustainable use of mobile payments.

Hypothesis 7 test results show a positive and significant effect between Trust and Perceived Risk with a Critical Ratio of 3.036 and P-value of $0.002<0.05$ or $5 \%$. The Critical Ratio value is greater than 1.96. So it can be concluded that hypothesis 7 is not supported by the results of this study. The results of this study are not in line with those of Lu et al. [26] and Shao et al. [36] who found that trust had a significantly negative effect on perceived risk. Go-Pay and OVO are still relatively young developing companies. Therefore, it does not rule out the possibility of a high risk in the use of Go-Pay and OVO. Go-Pay and OVO users believe and want to use both of these mobile payment services, but also realize the high risk because both of these services are still relatively new. Go-Pay and OVO users who were respondents of this study were mostly women aged 23-30 years. These respondents have the characteristics of risk taking. So that respondents who have trust in mobile payment services dare to take risks to use Go-Pay and OVO services that are relatively new.

While hypothesis 8 shows a negative and significant effect between Perceived Risk and Continuance Intention with a Critical Ratio of -1.892 and a P-value of 0.058 . Hypothesis 8 is significant at the $10 \%$ significance level and the Critical Ratio value $>1,645$. This means that hypothesis 8 is supported by the results of this study. Perceived Risk has a negative effect on Continuance Intention. The results of this study support the research of Shao et al. [36] which states that perceived risk has a negative effect on continuance intention. The results of this study also support the research of Lu et al. [26] and Liébana-Cabanillas [24]. Perceived risk is the user's perception of the risk of the mobile payment service used. Xin et al in Shuhaiber [37] state that perceived risk can raise doubts in consumers regarding technology and the ability of a service provider to provide electronic payment services. According to Liébana-Cabanillas [24], perceived risk can result in decreasing the desire to use services on an ongoing basis (continuance intention). Judging from the estimated value of this construct, the negative effect of perceived risk on continuance intention is not too large. In other words, the higher perception of Go-Pay and OVO users will lead to a risk that can reduce the user's desire to continue to use both of these mobile payment services. However, this influence is not too large and there are other possible factors that influence continuance intention. High risk might occur to GoPay and OVO because both of these mobile payment services are still developing and are young. From the results of the interviews, several respondents chose to continue using Go-
Pay and OVO for the time being because of the need for daily payment and other benefits, such as cashback promos.

\section{CONCLUSION}

The results of research and statistical testing using SPSS for Windows show that all variables have an average value above 3. Thus it can be concluded that the people has a positive perception of Go-Pay and OVO. Hypothesis testing using SEM method with AMOS program, shows that there are 4 supported hypotheses and 4 unsupported hypotheses. The specific explanation of the supported hypothesis is as follows.

1. Mobility has a positive effect on trust.

2. Security has a positive effect on trust.

3. Trust has a positive effect on continuance intention.

4. Perceived risk has a negative effect on continuance intention.

While the specific explanation of the unsupported hypothesis is as follows.

1. Customization has no effect on trust.

2. Reputation has no effect on trust.

3. Service quality has no effect on trust.

4. Trust has a positive effect on perceived risk.

This study has several limitations. The limitations of the study will be explained below along with recommendations for opportunities for further research. First of all, this research focuses on Go-Pay and OVO mobile payment services which are currently the most popular mobile payment services in Indonesia. There will be other mobile payment services that are more developed and popular in the future. So that future research can use other mobile payment services as research objects to test the reliability of the research model.

Each mobile payment service has different features, such as OVO points that Go-Pay does not have. The difference in features and appearance is the uniqueness that distinguishes mobile payment services from one another. Further research should focus on 1 mobile payment service so that the research is more focused and clear in the assessment of related variable indicators. Thus, the results of the study will be beneficial for the development of the mobile payment service.

Future studies can further examine the effects of construct customization, reputation, and service quality on trust. Some previous studies examined other variables that influence trust, such as perceived ease of use, social influence, customer satisfaction, etc. So that further research can add other constructs to find out the factors that influence trust in mobile payment users.

This study only examined one variable that affected perceived risk, namely trust. Future studies can examine the factors that influence perceived risk, such as presence of third parties, availability, controllability, etc. Thus, this construct becomes clearer and more complete.

\section{REFERENCES}

[1] J. Agusta, W. Adi, H. Muksit, K. Hutabarat, A. Hanzdima. Mobile Payments in Indonesia: Race to Big Data Domination. Jakarta : MDI Ventures-Mandiri Sekuritas, 2017. 
The $1^{\text {st }}$ International Conference on Business and Engineering Management (IConBEM)

February $1^{\text {st }} 2020$, Institut Teknologi Sepuluh Nopember, Surabaya, Indonesia

[2] APJII. Infografis Penetrasi dan Perilaku Pengguna Internet Indonesia. Jakarta: Teknopreneur, 2017.

[3] Y. A. Au, R.J. Kauffman. "The economics of mobile payments: Understanding stakeholder issues for an emerging financial technology application". Electronic Commerce Research and Applications, Vol.7, 2, 141-164, 2008.

[4] S. Ba. "Establishing online trust through a community responsibility system". Decision Support System Vol.31(3):323336, 2001.

[5] Bachfischer, E.M. Lawrence, R.J. Steele. "Towards understanding of factors influencing user acceptance of mobile payment systems". IADIS Internasional Conference WWW/Internet. IADIS Press, 2004.

[6] Bank Indonesia. "Financial Technology". [Online]. Available: https://www.bi.go.id/id/edukasi-perlindungan-

konsumen/edukasi/produk-dan-jasa-

sp/fintech/Pages/default.aspx, 2019 a.(Accessed : 25-March-2019)

[7] Bank Indonesia. "Tabel Jumlah Uang Elektronik Beredar". [Online]. Available: https://www.bi.go.id/id/statistik/sistempembayaran/uang-

elektronik/Contents/Jumlah\%20Uang\%20Elektronik.aspx, 2019b. (Accessed : 25-March-2019)

[8] I.L.A. Bhaskara. "Mengapa Sistem Pembayaran Elektronik NonTunai Bikin Kita Boros?". [Online]. Available: https://tirto.id/mengapa-sistem-pembayaran-elektronik-non-tunaibikin-kita-boros-c9ra, 2018. (Accessed : 12-May-2019)

[9] N, Dlodlo. “The Relationships among Service Quality, Trust, User Satisfaction and Post-Adoption Intentions in M-payment Services". Mediterranean Journal of Social Sciences, Vol.5, No. 23:165-175, 2014.

[10] Frima. "Daftar 10 Kota Terbesar di Pulau Jawa". [Online]. Available: http://informasi-daftar.blogspot.com/2017/12/daftar10-kota-terbesar-di-pulau-jawa.html, 2017. (Accessed : 2-May2019)

[11] S.L. Gia, T.T. Pham. "A Study of Factors Affecting the Intention to Use Mobile Payment Services in Vietnam". Economics World, Vol.4, No.6:249-273, 2016.

[12] I.Ghozali. Structural Equation Modeling, Metode Alternatif dengan Partial Least Square (PLS). Semarang: Badan Penerbit Universitas Diponegoro, 2014.

[13] J. Hair, W.C. Black, B.J. Babin, R.E. Anderson. Multivariate Data Analysis. Edisi 5. Jakarta: Gramedia Pustaka Utama, 2006. Tidak disitasi

[14] J. Hair, W.C. Black, B.J. Babin, R.E. Anderson. Multivariate Data Analysis, $7^{\text {th }}$ edition. New Jersey: Pearson Education Inc, 2010.

[15] J. Hair, W.C. Black, B.J. Babin, R.E. Anderson. Multivariate Data Analysis, $7^{\text {th }}$ edition (revised). New Jersey: Pearson Education Inc, 2014.

[16] L. Huang, X. Lu., S. Ba. "Building online trust in a culture of Confucianism: the impact of process flexibility and perceived control". ACM Transactions on Management Information Systems. 5(1):1-23, 2014.

[17] Y. Huwaydi, M.S. Hakim, S.F. Persada. "Analisis Deskriptif Pengguna Go-Pay di Surabaya”. Jurnal Teknik ITS, Vol. 7, No.1, A55-A59, 2018.

[18] ITU. "The Mobile Money Revolution Part 1: NFC Mobile Payments". Geneva : ITU-T Technology Watch, 2013.

[19] Katadata. "Usia Produktif Mendominasi Pengguna Internet". [Online]. Available: https://databoks.katadata.co.id/datapublish/2018/02/23/usiaproduktif-mendominasi-pengguna-internet, 2018. (Accessed : 16April-2019) tidak disitasi

[20] Katadata. "OVO Balap GO-PAY sebagai Dompet Elektronik Pilihan". [Online]. Available: https://www.msn.com/idid/ekonomi/ekonomi/ovo-balap-go-pay-sebagai-dompetelektronik-pilihan/ar-AACaT8T,2019. (Accessed : 25-July-2019)

[21] Khoirunnisa. "Top 5 Mobile Payment di Indonesia". [Online]. Available: https://selular.id/2019/01/top-5-mobile-payment-diindonesia-2018/, 2019. (Accessed : 29-March-2019)

[22] Kim, M. Mirusmonov, I. Lee. "An empirical examination of factors influencing the intention to use mobile payment". Computers in Human Behavior vol.26(3):310-322, 2010.
[23] Y.M. Li, Y.S. Yeh. "Increasing trust in mobile commerce through design aesthetics”. Computers in Human Behavior vol.26(4):673684, 2010.

[24] F. Liébana-Cabanillas, S. Molinilo, M. Ruiz-Montañez. "To use or not to use, that is the question: Analysis of the determining factors for using NFC mobile payment systems in public transportation". Technological Forecasting \& Social Change, 139:266-276, 2019.

[25] Y. Lu, L. Zhang, B. Wang. "A multidimensional and hierarchical model of mobile service quality". Electronic Commerce Research and Applications 8:228-240, 2009. Tidak disitasi

[26] Y. Lu, S. Yang, P.Y.K. Chau, Y. Cao. "Dynamics between the trust transfer process and intention to use mobile payment services:A cross-environment perspective". Information \& Management 48:393-403, 2011.

[27] D.H. McKnight, V. Choudhury, C. Kacmar. "The impact of initial consumer trust on intentions to transact with a web site: a trust building model". Journal of Strategic Information System 11:297323,2002 .

[28] H. Qasim, E. Abu-Shanas. "Drivers of mobile payment acceptance: The impact of network externalities". Information Systems Frontiers, Vol.18 No.5:1021-1034, 2016.

[29] L. Rahadian. "Industri Pembayaran Digital: Bank dan Fintech Berebut Pasar?" [Online]. Available: https://finansial.bisnis.com/read/20190225/90/893062/industripembayaran-digital-bank-dan-fintech-berebut-pasar, 2019 (Accessed : 16-July-2019)

[30] Ristekdikti. "Era Revolusi Industri 4.0, Saatnya Generasi Millennial menjadi Dosen Masa Depan”. [Online]. Available: http://sumberdaya.ristekdikti.go.id/index.php/2018/01/30/erarevolusi-industri-4-0-saatnya-generasi-millennial-menjadi-dosenmasa-depan/, 2018. (Accessed : 25-March-2019)

[31] J. Sarwono. "Pengertian Dasar Structural Equation Modeling (SEM)". [Online]. Available: http://www.jonathansarwono.info/sem/konsep_dasar_sem.htm, 2008. (Accessed : 20-May-2019)

[32] U. Sekaran, R. Bougie. Research method for business:a skillbuilding approach, $7^{\text {th }}$ edition. Chichester: John Wiley \& Sons, 2016.

[33] R. Septiani, P.W. Handayani, F. Azzahro. "Factors that Affecting Behavioral Intention in Online Transportation Service: Case study of GO-JEK". Procedia Computer Science 124: 504-512, 2017.

[34] S. Setiaji. "Penggunaan Mobile Payment di Indonesia Tumbuh". [Online]. Available: https://ekonomi.bisnis.com/read/20190613/9/933358/penggunaan -mobile-payment-di-indonesia-tumbuh, 2019. (Accessed : 16July-2019)

[35] Setyowati. "Dua Riset Sebut Go-Pay Dominasi Pasar Pembayaran Digital di Indonesia". [Online]. Available: https://katadata.co.id/berita/2019/01/22/dua-riset-sebut-go-paydominasi-pasar-pembayaran-digital-di-indonesia, (Accessed : 25-March-2019)

[36] Z. Shao, L. Zhang, X. Li, Y. Guo. "Antecedents of trust and continuance intention in mobile payment platforms:The moderating effect of gender". Electronic Commerce Research and Applications vol.33 no.100823:1-10, 2019.

[37] A.Shuhaiber. "Factors Influencing Consumer Trust in Mobile Payments in the United Arab Emirates". Victoria University of Wellington, 2016.

[38] P. Wanda. "Bagaimana Prospek Ekonomi Digital Indonesia di 2019?". [Online]. Available: https://www.kompasiana.com/wpwawan/5c5afa1fc112fe22d20df 243/bagaimana-prospek-ekonomi-digital-indonesia-di2019?page $=$ all, 2019. (Accessed $:$ 25-March-2019)

[39] N.Wang, X. Shen, Y. Sun. "Transition of electronic word-ofmouth services from web to mobile context: A trust transfer perspective". Decision Support Systems, Vol.54 No.3:1394-1403, 2013.

[40] L. Yu, X. Cao, Z. Liu, M. Gong, L. Adeel. "Understanding mobile payment users' continuance intention: a trust transfer perspective". Internet Research, 2018.

[41] T. Zhou. "An empirical examination of continuance intention of mobile payment services". Decision Support Systems,54:10851091, 2013. 